Adıyaman Üniversitesi Sağlık Bilimleri Dergisi, 2020;6(1):68-76

doi:10.30569.adiyamansaglik.669761

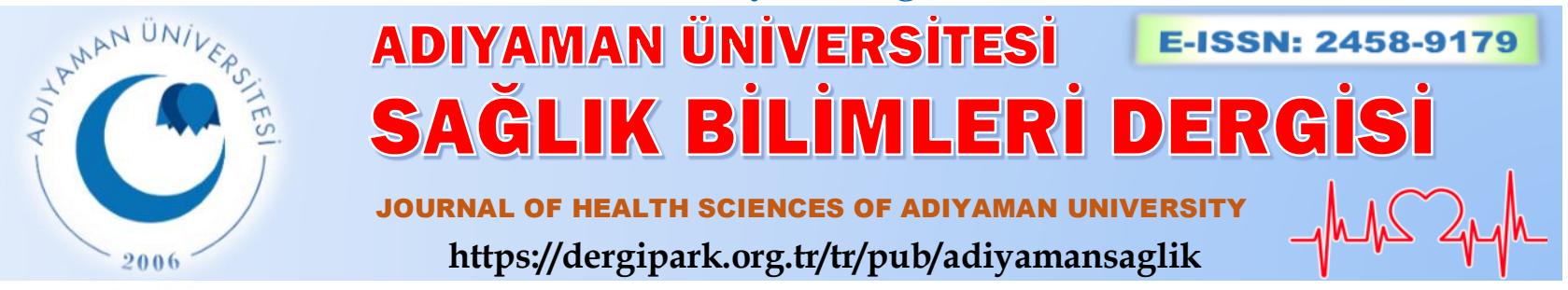

Özgün Araştırma/Research Article

\title{
Öğrencilerin yaşlı ayrımcılığına ilişkin tutumları: bir üniversite örneği
}

\section{Attitudes of students towards ageism: an example of university}

\author{
Rana CAN ${ }^{1 @(D), ~ H a t i c e ~ T A M B A G ̆ ~}{ }^{2}(D)$ Esra DOĞRU HÜZMELI' ${ }^{2}$ (D) Fatma DUMAN ${ }^{3}(D)$ \\ ${ }^{1}$ Akdeniz Üniversitesi, Tıp Fakültesi, Tıp Tarihi ve Etik Anabilim Dalı, 07070, Antalya-Türkiye \\ ${ }^{2}$ Mustafa Kemal Üniversitesi, Sağlık Bilimleri Fakültesi, Tayfur Sökmen Kampüsü, 31060, Hatay-Türkiye \\ ${ }^{3}$ Mustafa Kemal Üniversitesi, Tayfur Sökmen Tıp Fakültesi, Tayfur Sökmen Kampüsü, 31060, Hatay-Türkiye
}

Atıf gösterme/Cite this article as: Can R, Tambağ H, Hüzmetli Doğru E, Duman F. Öğrencilerin yaşlı ayrımcılığına ilişkin tutumları: bir üniversite örneği. ADYÜ Sağlık Bilimleri Derg. 2020;6(1):68-76. doi:10.30569.adiyamansaglik.669761

\section{$\ddot{O} z$}

Amaç: Bu çalışmada sağlık alanında eğitim gören genç nüfusun 65 yaş ve üzeri bireylere karşı tutumlarını belirlemek amacıyla planlanmıştır.

Gereç ve Yöntem: Çalışmada veri toplama formunun ilk bölümünde sosyodemografik özellikleri belirlemeye yönelik sorulardan ve Yaşlı Ayrımcılığı Tutum Ölçeği'nden oluşmaktadır. Araştırmanın evrenini 745 öğrenci oluşturmaktadır. Verilerin değerlendirilmesinde sayı ve yüzde değerleri, Independent Sample t Test, One-Way Anova Testi ve Bonferroni Testi kullanılmıştır

Bulgular: Katılımcıların \%55,3’ü hemşirelik bölümü öğrencisi; \%62,3'ü kadındır. Yaş ortalaması 20,46 $\pm 1,90$ 'dır. Toplam ölçek puan ortalamas1 $85,09 \pm 9,53$ bulunmuştur. Katılımcının okuduğu bölüm, cinsiyeti, ebeveyn eğitim düzeyi, kardeş sayısı, aile yapısı, aile kurduğunda anne baba ile yaşamayı isteme durumu ile ölçek puan ortalamaları arasında anlamlı fark bulunmuştur $(p<0,005)$.

Sonuç: Çalışmada öğrencilerin yaşlı ayrımcılığına ilişkin olumlu tutumları olduğu; yaşlı bireylere karşı tutumlarını etkileyen kimi sosyo-demografik değişkenlerin olduğu saptanmıştır.

Anahtar Kelimeler: Yaşlı ayrımcılığı; Hemşirelik; Fizyoterapi; Yaşlılık.

\begin{abstract}
Aim: In this study, young people who are training in the health field 65 years and over is planned in order to determine their attitudes towards individuals.

Materials and Methods: Ageism Attitude Scale and data collection forms will be used to. The research population is 745 students. Number and percentage values, Independent Sample t Test, One-Way Anova Test and Bonferroni Test were used to evaluate the data.

Results: $55.3 \%$ of the participants were nursing students, $62.3 \%$ are women, average age of was $20.46 \pm 1.90$. The average scale total score was $85.09 \pm 9.53$. There was a significant difference $(p<0.005)$ between the part, gender, parental education, number of siblings, family structure, expectancy of life with parents when they have a family and scale score averages.

Conclusion: The students had positive attitudes towards the elderly discrimination; some sociodemographic variables affecting their attitudes towards elderly.
\end{abstract}

Keywords: Ageism; Nursing; Physiotherapy; Elderly.

Yazışma Adresi/Address for Correspondence: Dr. Rana CAN, Akdeniz Üniversitesi, Tıp Fakültesi, Tıp Tarihi ve Etik Anabilim Dal1, 07070, Antalya-Türkiye, E-mail: rcan0131@ gmail.com

Geliş Tarihi/Received:03.01.2020 Kabul Tarihi/Accepted:17.03.2020 Yayım Tarihi/Published online:23.04.2020 


\section{Giriş}

Yaşlı nüfusun dünya ölçeğinde artmasıyla, tüm hizmet alanlarında ve toplumsal alanda yaşlılara yönelik yaklaşımlar ve çalışmalar önem kazanmaktadır. Özellikle tıp ve teknolojideki gelişmeler ile yaşam süresinin uzaması, yaşlı kişilerin daha fazla sağlık hizmeti tüketicisi olması, hem tıbbın hem de sağlık profesyonellerinin onlara yönelik ilgisinin arttırmıştır. Bu bağlamda geriatri ve gerontoloji alanı kimi diğer bilim dallarına göre görece daha yeni olmakla beraber alana özgü kavramlar da yeni yeni tartışılmaya başlanmıştır.

Yaşlılık, başlı başına bir hastalık olarak nitelendirilmesi uygun olmayan, birçok farkl1 boyutu içeren karmaşık bir süreçtir. Bu süreci yaşayanların oranı azımsanmayacak kadar çoktur. 2014 yılında dünya nüfusunun \%8,3’ü yaşlı nüfustur. ${ }^{1}$ Ulusal ölçekte bakıldığında yaşlı nüfus (65 ve daha yukarı yaş) 2014 yılında 6 milyon 192 bin 962 kişi olup yaşlı nüfusun toplam nüfus içindeki oran1 $\% 8$ olmuştur. TÜİK'e göre yaşlı nüfus oranının 2023 y1linda \%10,2, 2050 yilinda \%20,8, 2075 y1lında ise \%27,7'ye yükseleceği tahmin edildi. ${ }^{1}$

Geriatri-gerontolojinin tıptaki ağırlığının son on yıllarda giderek artması yaşlılık ve yaşlanma ile ilgili kavramların ve sorunların tartışılmasını gündeme getirmiştir. $\mathrm{Bu}$ alandaki kavramlardan biri de yaşlı ayrımcılığıdır. Vefikuluçay çalışmasında yaşlı ayrımcılığının Palmore tarafindan "ileri yaştaki bireylere yönelik ön yargıyı, tutum ve davranışlar aracılı̆̆ 1 ile ifade eden bir terim" olarak kullanıldığını belirtmiştir. ${ }^{2}$ Literatürde yaşlı ayrımcılığına bakış açısının negatif ve pozitif ayrımcılık olmak üzere iki yönde yer aldığ1 görülmektedir. ${ }^{3-7}$ Genç nüfusun bir kısmını oluşturan üniversite öğrencileri kişisel değerlerini mesleki bilgi beceri ve etik değerleri ile harmanlayarak alanlarında hizmet verecek profesyoneller olarak mezun olmaktadırlar. Yaşı sağlığı son yıllarda sadece tıbbın değil diğer meslek gruplarının da ilgi alanına girmiştir. Üniversitelerin tıp fakülteleri dişında hemşirelik, diş hekimliği, eczacilı, fizyoterapi ve rehabilitasyon, ev ekonomisi, beslenme ve diyetetik, sosyal hizmetler, psikoloji, mimarlık ve çevre tasarımı gibi bölümlerinde de yaşlı sağlığı ile ilgili-bağlantılı çalışmalar yürütülmektedir. ${ }^{8-11}$ Literatürde yaşlıya yönelik tutumların olumsuz olmasının meslek yaşamında yaşlıyı ihmal etme ya da olumsuz yönde yaşlı ayrımcılığına yol açabileceğ $\mathrm{i}$ vurgulanmaktadır. ${ }^{12,13}$ Özellikle uğraş alanı insan olan sağlıkla ilgili mesleklerde yaşlıya yönelik tutum mesleki pratiğe yansımaktadır. Hemşirelik ve fizyoterapi ve rehabilitasyon eğitimi alan öğrenciler meslek üyesi olarak yaşlanan topluma hizmet sunmaya adaydırlar ve eğitimleri süresince de yaşlı ve yaşlılık konusunda ders almaktadırlar. Sağlık hizmeti sunan profesyonellerin yaşlı ayrımcılığına bakış açısı verilen sağlık hizmetine yansımaktadır. Bu da hizmet sunum kalitesini ve hasta memnuniyetini etkilemektedir.

Literatürde özellikle hemşireler ve hemşirelik öğrencilerinin yaşlıya/yaşlılığa yönelik tutum ve inanışlarını belirlemeye yönelik çalışmalar yer almaktadır., ${ }^{9,10,14,15}$ Fizyoterapist/fizyoterapi öğrencilerine yönelik daha az çalışmaya her iki meslek grubu katılımcılarının birlikte yer aldığı konu ilgili bağ lantılı çalışmaya rastlanmamıştır.

$\mathrm{Bu}$ çalışmanın amacı, sağlık alanında hemşirelik ile fizyoterapi ve rehabilitasyon bölümünde eğitim gören genç nüfusun 65 yaş ve üzeri bireylere karşı tutumlarını belirlemek ve yaşlı ayrımcılığ 1 konusunda farkındalık yaratmaktır.

\section{Gereç ve Yöntem}

\section{Araştırmanın Tipi}

Araştırma tanımlayıcı bir çalışmadır.

\section{Araştırmanın Evren ve Örneklemi}

Araştırmanın evrenini 2015-2016 akademik yılında A Üniversitesi Sağlık Yüksekokulu Hemşirelik Bölümü'nde ve Fizik Tedavi ve Rehabilitasyon Yüksekokulu'nda kayıtlı 745 öğrenci oluşturmaktadır. Çalışmada örneklem seçimine gidilmeyip aktif olarak okulda bulunan öğrencilerden bilgilendirme sonrası gönüllü olarak araştırmaya katılmayı kabul eden öğrenciler çalışma kapsamına alınmıştır. Araştırmaya katılmayı kabul eden, veri toplama formunu eksiksiz dolduran ve derse devam eden 599 öğrenci örneklemi 
oluşturmuştur. Çalışmada evrenin \%80,40’na ulaşılmıştır.

\section{Veri Toplama Araçları}

Tanımlayıcı tipteki bu çalışmada veri toplama formu iki bölümden oluşmaktadır. İlk bölümde katılımcıların sosyo-demografik özelliklerini belirlemeye yönelik araştırmacılar tarafından literatür taranarak hazırlanan 13 soru $^{2,16}$ ikinci bölümde ise 2008 yılında geliştirilen Yaşlı Ayrımcılığı Tutum Ölçeği (YATÖ) yer almaktadır. Veri toplama formu araştırmacılar tarafindan katılımcılara uygulanmış olup doldurulması yaklaşık 5-7 dakika sürmüştür. İlk bölümdeki 13 soru sosyo-demografik özellikleri ve aileye ilişkin özellikleri belirlemeye yöneliktir.

Vefikuluçay tarafından 2008 yılında geliştirilen Yaşlı Ayrımcılı̆̆ (YATÖ), "yaşlının yaşamını sınırlamaya", "yaşlıya yönelik olumlu ayrımcılık" ve "yaşlıya yönelik olumsuz ayrımcılık" konularını içeren üç alt boyuttan ve 23 maddeden oluşan bir ölçektir. Ölçekte yer alan maddeler "Kesinlikle Katılmiyorum", "Katılmiyorum", "Kararsizım", "Kat1liyorum" ve "Tamamen Kat1lyorum" seçenekleri olan 5'li Likert tipindedir. Yaşl1 Ayrımcilı̆ğ Tutum Ölçeği (YATÖ)'den alınabilecek maksimum puan "115", alınabilecek minimum puan "23"dür. ${ }^{2}$ YATÖ’nün "yaşlının yaşamını sınırlama” alt boyutu puan ortalamasinın " 45 "e yakın olması, öğrencinin yaşlının yaşamını sınırlama boyutuna ilişkin tutumunun olumlu olduğunu göstermektedir. YATÖ'nün "yaşlının yaşamını sınırlama" alt boyutu puan ortalamasının "9"a yakın olması, öğrencinin yaşlının yaşamını sınırlama boyutuna ilişkin tutumunun olumsuz olduğunu göstermektedir. YATÖ'nün “yaşlıya yönelik olumlu ayrımcılık" alt boyutu puan ortalamasinın "40"a yakın olması, yaşlıya yönelik olumlu ayrımcılık boyutuna ilişkin olumlu tutuma sahip olduğunu göstermektedir. YATÖ’nün "yaşlıya yönelik olumlu ayrımcılık" alt boyutu puan ortalamasinın "8"e yakın olmas1, yaşlıya yönelik olumlu ayrımcılık boyutuna ilişkin olumsuz tutuma sahip olduğunu göstermektedir. ${ }^{2}$ YATÖ'nün “yaşlıya yönelik olumsuz ayrımcilık" alt boyutu puan ortalamasının “30”a yakın olması, öğrencinin yaşlıya yönelik olumsuz ayrımcılık boyutuna ilişkin tutumunun olumlu olduğunu göstermektedir. YATÖ’nün "yaşlıya yönelik olumsuz ayrımcilık" alt boyutu puan ortalamasının "6"ya yakın olması, öğrencinin yaşlıya yönelik olumsuz ayrımcılık boyutuna ilişkin tutumunun olumsuz olduğunu göstermektedir.

\section{Verilerin Analizi}

Veriler araştırmacılar tarafindan bilgisayara aktarılmış ve istatistiksel analizleri SPSS (Statistics Package for Social Sciences) 22.0 paket programında araştırmacı tarafindan yapılmıştır. Verilerin değerlendirilmesinde sayı ve yüzde değerleri, Independent Sample t Test, One-Way Anova Testi ve Bonferroni Testi kullanılmıştır.

\section{Araştırmanın Etik Yönü}

Çalışma için ilgili üniversitenin Klinik Araştırmalar Etik Kurulu'ndan izin alınmıştır. (22.10.2015 tarihli toplant1 Karar No: 4). Çalışma, Helsinki Bildirgesi ilkelerine bağlı kalarak yürütülmüştür.

\section{Bulgular}

Katılımcıların yaş ortalaması $20,46 \pm 1.90$ olup \%62,30'u kadın ve \%55,30'u hemşirelik bölümündendir. Katılımc1ların \%25,30’u ikinci sınıf öğrencisidir. \% 25,20'inde kardeş sayıs1 iki olup \%86,10'u çekirdek ailedir. Ebeveynlerin eğitim durumuna bakıldı̆̆ında $\% 43,60$ 'ının anne eğitimi ilkokul, \%35,40'ının babası ilkokul mezunudur. Katılımciların \%80,01'inin büyükbaba büyükannesi hayatta olup; \% 64,90'1 evlenince anne/babasıyla yaşamak istemektedir (Tablo 1).

Çalışmamızda toplam YATÖ puan ortalamas1 85,09 $\pm 9,53$ olup bu değer katılımcıların yaşlıya yönelik olumlu tutum içinde olduklarına göstermektedir. Ölçeğin üç alt boyutuna bakıldığında; yaşamını sınırlama puan ortalamas $136,51 \pm 4,61$ 'dır. İkinci alt boyut olan yaşlıya yönelik olumlu ayrımcılık puan ortalaması $31,16 \pm 5,32$ olup bu öğrencilerin yaşliya olumlu tutuma sahip olduklarını göstermektedir. 
Tablo 1. Katılımcıların sosyodemografik özellikleri.

\begin{tabular}{|c|c|c|}
\hline Bireysel özellikler & Sayı (599) & $\%$ \\
\hline \multicolumn{3}{|l|}{ Bölüm } \\
\hline FTR & 268 & 44,7 \\
\hline Hemşirelik & 331 & 55,3 \\
\hline \multicolumn{3}{|l|}{ Cinsiyet } \\
\hline Kadın & 373 & 62,3 \\
\hline Erkek & 226 & 37,7 \\
\hline \multicolumn{3}{|l|}{ Yaş $(20.46 \pm 1.90)$} \\
\hline $17-19$ & 182 & 30,4 \\
\hline $20-22$ & 374 & 62,4 \\
\hline 23 ve üstü & 43 & 7,2 \\
\hline \multicolumn{3}{|l|}{ Sinıf } \\
\hline 1 & 150 & 25,0 \\
\hline 2 & 151 & 25,2 \\
\hline 3 & 148 & 24,7 \\
\hline 4 & 150 & 25,0 \\
\hline \multicolumn{3}{|l|}{ Medeni durum } \\
\hline Evli & 19 & 3,2 \\
\hline Bekar & 580 & 96,8 \\
\hline \multicolumn{3}{|l|}{ Kardeş sayısı } \\
\hline Yok & 12 & 2,0 \\
\hline 1 & 87 & 14,5 \\
\hline 2 & 165 & 27,5 \\
\hline 3 & 140 & 23,4 \\
\hline 4 & 83 & 13,9 \\
\hline 5 ve üstünde & 112 & 18,7 \\
\hline \multicolumn{3}{|l|}{ Aile yapısı } \\
\hline Çekirdek & 516 & 86,1 \\
\hline Geniş & 83 & 13,9 \\
\hline \multicolumn{3}{|c|}{ En uzun yaşanılan yer } \\
\hline İl & 273 & 45,6 \\
\hline İlçe & 215 & 35,9 \\
\hline Köy & 111 & 18,5 \\
\hline \multicolumn{3}{|c|}{ Ailesinin gelir durumu } \\
\hline Gelir giderden az & 372 & 62,1 \\
\hline Gelir gidere denk & 150 & 25,0 \\
\hline Gelir giderden fazla & 77 & 12,9 \\
\hline \multicolumn{3}{|l|}{ Anne eğitim düzeyi } \\
\hline Okuryazar değil & 83 & 13,9 \\
\hline Okuryazar & 43 & 7,2 \\
\hline İlkokul & 261 & 43,6 \\
\hline Ortaokul & 93 & 15,5 \\
\hline Lise & 91 & 15,2 \\
\hline Üniversite & 28 & 4,7 \\
\hline \multicolumn{3}{|l|}{ Baba eğitim düzeyi } \\
\hline Okuryazar değil & 21 & 3,5 \\
\hline Okuryazar & 22 & 3,7 \\
\hline İlkokul & 212 & 35,4 \\
\hline Ortaokul & 125 & 20,9 \\
\hline Lise & 123 & 20,5 \\
\hline Üniversite & 96 & 16,0 \\
\hline \multicolumn{3}{|c|}{ Büyükanne/büyükbabanın yașadığı yer } \\
\hline Benim ailemle & 52 & 8,7 \\
\hline Kendi evlerinde & 249 & 41,6 \\
\hline $\begin{array}{l}\text { Birinci derece } \\
\text { yakınlarımla }\end{array}$ & 179 & 29,8 \\
\hline Hayatta değiller & 119 & 19,9 \\
\hline \multicolumn{3}{|c|}{$\begin{array}{l}\text { Aile kurduğunda anne/baba ile birlikte yaşamayı } \\
\text { isteme durumu }\end{array}$} \\
\hline İsteyen & 389 & 64,9 \\
\hline İstemeyen & 210 & 35,1 \\
\hline
\end{tabular}

Üçüncü alt boyut olan yaşlyya yönelik olumsuz ayrimcilik puan ortalamas1 $17,41 \pm 3,54$ olup öğrencilerin yaşlyya yönelik olumsuz ayrımc1lı alt boyutuna ilişkin daha olumlu tutuma sahip olduklarını göstermektedir (Tablo 2). Çalış̧mamızda toplam ölçek Cronbach's Alpha değeri 0,77 bulunmuştur.

Çalışmamızda YATÖ puan ortalaması ile öğrencinin okuduğu bölüm arasındaki ilişkiye bakıldığında yaşlının yaşamını sınırlama alt boyutunda anlamlı fark bulunmuştur $(p=0.006)$. Fizyoterapi öğrencilerinin yaşlının yaşamını sınırlama alt boyut puan ortalaması daha yüksek bulunmuştur. Benzer şekilde cinsiyetlerle puan ortalamaları arasındaki ilişkiye bakıldığında cinsiyetler ile yaşlının yaşamını sınırlama alt boyutu arasında anlamlı fark bulunmuştur $(p=0.029)$. Cinsiyet açısından bakıldığında kadınların yaşlının yaşamını sinırlama alt boyutu puan ortalaması daha yüksek bulunmuştur. Ayrıca kadınların YATÖ puan ortalaması erkeklere göre daha yüksektir (Tablo 3). Aile yapısı ile YATÖ toplam puan ve alt gruplar arasındaki ilişkiye bakıldığında aile yapısı ile yaşlıya yönelik olumlu ayrımcilık $(p=0.001)$ ve YATÖ toplam puan ortalaması arasinda anlamlı fark bulunmuştur $\quad(p=0.036)$. Çalışmamızda katılımcıların evlenince anne/baba ile yaşama isteği ve ölçek toplam puan ve alt grup toplam puanları arasındaki ilişkiye bakıldığında yaşlıya yönelik olumlu ayrımcılık $(p=0.001)$ ve YATÖ toplam puan ortalaması arasında anlamlı fark bulunmuştur $(p=0.001)$. Ayrica kardeş sayısı ve yaşlıya yönelik olumlu ayrımcilık puan ortalaması arasında anlamlı fark $(p=0.020)$ olup kardeş sayısı 5 ve üzeri olanlarda puan ortalaması daha yüksektir (Tablo 3).

Katılımcıların anne eğitim düzeyi ile YATÖ toplam puan ve alt grup puan ortalamaları arasındaki ilişkiye bakıldığında yaşlıya yönelik olumlu ayrımcılık puan ortalaması $(p=0.001)$ ve YATÖ toplam puan ortalaması $(p=0.036)$ arasinda anlamlı fark bulunmuştur. Katılımcıların baba eğitim durumu ile ölçek toplam puan ortalaması ve yaşlıya yönelik olumsuz ayrımcılık alt grup puan ortalamas1 arasinda anlamlı fark bulunmuştur ( $p=0.011)$. 
Tablo 2. Öğrencilerin yaşlı ayrımcılı̆̆ı tutum ölçeği puanları.

\begin{tabular}{lll}
\hline Yaşlı Ayrımcılı̆̆ı Tutum Ölçeği Boyutları & $\overline{\mathbf{X}} \pm \mathbf{S S}$ & $\mathbf{m i n}-\mathbf{m a x}$ \\
\hline Yaşlının yaşamını sınırlama & $36.51 \pm 4.61$ & $13-45$ \\
Yaşlıya yönelik olumlu ayrımcılık & $31.16 \pm 5.32$ & $8-40$ \\
Yaşlıya yönelik olumsuz ayrımcılık & $17.41 \pm 3.54$ & $6-27$ \\
Toplam YATÖ & $85.09 \pm 9.53$ & $27-111$ \\
\hline
\end{tabular}

Çalışmamızda katılımcıların genel olarak YATÖ puan ortalamalarına bakıldığında fizyoterapi öğrencilerinin yaşlıya yönelik tutumlarının daha olumlu olduğu görülmektedir. Kardeş sayısı fazla olanların, kadınların, geniş aileye sahip olanların ve ileride ailesi ile birlikte yaşamayı isteyenlerin tutumlarının daha olumlu saptanmıştır. Çalışmamızda medeni durum, okuduğu sınıf, gelir durumu ve en uzun yaşanılan yer ile ölçek puan ortalamaları arasında anlamlı fark bulunmamıştır $(p>0,05)$.

\section{Tartışma}

Çalışmamızda katılımcıların genel olarak yaşlıya yönelik olumlu tutuma sahip olduğu, kimi sosyo-demografik değişkenlerin yaşlıya yönelik tutumda etkili olduğu saptanmıştır. Literatürde yaşlı ayrımcılığına yönelik çalışmalar yapılmış olup fizyoterapi ve hemşirelik ögrrencilerinin birlikte yer aldığ 1 çok sınırlı sayıda çalışmaya rastlanmamıştır.

Vefikuluçay’ın çalışmasında yaşanılan yer, babalarının öğrenim düzeyi, yaşl1/yaşlılar ile aynı evde yaşama durumu, büyükannebüyükbabanın yaşadığı yer, aile kurduktan sonra ebeveynleri ile yaşamayı isteme durumu ile ölçek puan ortalamaları arasında anlamlı fark bulunmamıştır. ${ }^{2}$ Soyuer ve ark.'larının çalışmasında aile yapısı ile yaşlının yaşamını sınırlama alt grup ölçek puan ortalamaları arasında anlamlı fark bulunmuştur $(p<0.05) .{ }^{17}$ Çalışmamızda ise yaş, medeni durum, sınıf, en uzun yaşanılan yer, gelir durumu ve büyükanne/büyükbabanın yaşadıkları yere ilişkin soru ile ölçek puan ortalaması arasında anlamlı fark bulunmamıştır $\quad(p>0.05)$. Dolayısıyla yaşlıya ilişkin tutumlarda kimi farklı sosyo-demografik değişkenlerin etkili olmadığını söylemek olanaklıdır.

Söderhamn ve ark. çalışmasında hemşirelik öğrencilerinden birinci sınıfta okuyanların diğer siniflara göre yaşlı ayrımcılığ 1 konusunda daha olumsuz tutumları olduğunu belirtilmiştir. ${ }^{9}$ Aynı çalışmada 25 yaşından küçük öğrencilerin yaşlı ayrımcılığ 1 konusunda daha olumsuz tutuma sahip oldukları ancak hemşirelerde yaş grupları arasında fark saptanmamıştır. ${ }^{9}$ Kulakçı'nın birinci ve dördüncü sınıf öğrencilerinin yaşlılığa ilişkin görüşlerini belirlediği çalışmasında dördüncü sınıf öğrencilerinin yaşlanma ve yaşlilığa ilişkin birinci sınıf öğrencilerine göre daha olumlu düşünce ve görüşlere sahip oldukları görülmektedir. ${ }^{18}$ Yılmaz ve Özkan'ın çalışmasında YATÖ alt boyutlarından yaşlıya yönelik olumlu ve olumsuz ayrımcılık puan ortalamaları ile sınıf arasında istatistiksel olarak anlamlı bir fark belirlenmiştir $(p<0.05) .{ }^{19}$

Bir diğer çalışmada katılımcıların YATÖ'nin yaşlı yaşamını sınırlama alt grubu puan ortalaması ile öğrenim gördükleri sınıf arasında istatistiksel açıdan anlamlılık bulunmuştur $(p<0.05) .{ }^{22}$ Çalışmamızda sınıf ile ölçek puan ortalamaları arasında anlamlı fark bulunmamıştır $(p>0.05)$.

Tıp öğrencileri üzerinde yapılan çalışmada kadın katılımcıların yaşlıya ilişkin daha olumsuz tutumlarının olduğu; birinci sınıf öğrencilerinin yaşlıya yönelik olumsuz tutum puanlarının daha yüksek olduğu saptanmıştır. $^{20}$ Hemşirelik öğrencileri üzerinde yapılan çalışmada ise sınıf ile yaşlıya yönelik olumlu ayrımcılık puan ortalaması arasında anlamlı fark bulunmuş olup son sınıf öğrencilerinin puan ortalaması daha yüksek bulunmuştur. ${ }^{14}$ Aynı çalışmada ölçek toplam puan ortalaması ile olumsuz ayrımcılık alt grubu ile toplam ortalama puan ortalamas1 arasinda anlamlı fark $(p<0.05)$ bulunmuştur. ${ }^{14}$ Hemşirelik öğrencileri üzerinde yapılan bir diğer çalışmada birinci sınıf öğrencilerinin ve ileride ailesi ile birlikte yaşamak isteyenlerin puan ortalamaları daha yüksek bulunmuştur. ${ }^{21}$ Ayrıca bu çalışmadaki YATÖ toplam puan ortalaması çalışmamız ile benzerlik göstermektedir. ${ }^{21}$ 
Tablo 3. Öğrencilerin sosyodemografik özelliklerine göre YATÖ puan ortalamaları.

\begin{tabular}{|c|c|c|c|c|c|}
\hline Özellikler & $\mathbf{n}$ & $\begin{array}{l}\text { Yaşlının } \\
\text { yaşamını } \\
\text { Sınırlama } \\
\overline{\mathbf{X}} \pm \text { SS }\end{array}$ & $\begin{array}{l}\text { Yaşlıya yönelik } \\
\text { olumlu } \\
\text { ayrımcılık } \\
\overline{\mathbf{X}} \pm \mathrm{SS}\end{array}$ & $\begin{array}{l}\text { Yaşlıya yönelik } \\
\text { olumsuz } \\
\text { ayrımcılık } \\
\overline{\mathbf{X}} \pm \text { SS }\end{array}$ & $\begin{array}{l}\text { Toplam YATÖ } \\
\overline{\mathbf{X}} \pm \text { SS }\end{array}$ \\
\hline \multicolumn{6}{|l|}{ Bölüm } \\
\hline FTR & 268 & $37.08 \pm 4.32$ & $31.13 \pm 5.19$ & $17.67 \pm 3.44$ & $85.89 \pm 9.21$ \\
\hline \multirow[t]{3}{*}{ Hemşirelik } & 331 & $36.05 \pm 4.79$ & $31.19 \pm 5.43$ & $17.20 \pm 3.61$ & $84.45 \pm 9.74$ \\
\hline & & $*_{\mathrm{t}}=2.736$ & $*_{\mathrm{t}}=-0.136$ & $*_{\mathrm{t}}=1.606$ & $* \mathrm{t}=1.840$ \\
\hline & & $p=0.006$ & $p=0.892$ & $p=0.109$ & $p=0.066$ \\
\hline \multicolumn{6}{|l|}{ Cinsiyet } \\
\hline Kadın & 373 & $36.83 \pm 4.37$ & $31.17 \pm 4.97$ & $17.36 \pm 3.60$ & $85.37 \pm 9.24$ \\
\hline \multirow[t]{3}{*}{ Erkek } & 226 & $35.98 \pm 4.94$ & $31.14 \pm 5.87$ & $17.50 \pm 3.44$ & $84.63 \pm 9.98$ \\
\hline & & $* \mathrm{t}=2.192$ & $* \mathrm{t}=0.079$ & $* \mathrm{t}=-0.492$ & $* \mathrm{t}=0.919$ \\
\hline & & $p=0.029$ & $p=0.937$ & $p=0.623$ & $p=0.359$ \\
\hline \multicolumn{6}{|l|}{ Kardeş sayısı } \\
\hline Yok & 12 & $34.50 \pm 6.78$ & $27.83 \pm 8.45$ & $18.66 \pm 3.74$ & $81.00 \pm 12.11$ \\
\hline 1 & 87 & $36.71 \pm 5.02$ & $30.91 \pm 5.30$ & $17.12 \pm 3.67$ & $84.75 \pm 10.54$ \\
\hline 2 & 165 & $36.67 \pm 3.98$ & $30.55 \pm 4.54$ & $17.47 \pm 3.29$ & $84.70 \pm 8.33$ \\
\hline 3 & 140 & $36.34 \pm 4.58$ & $31.14 \pm 5.01$ & $17.71 \pm 3.45$ & $85.20 \pm 9.01$ \\
\hline 4 & 83 & $36.09 \pm 4.49$ & $31.48 \pm 5.39$ & $17.22 \pm 3.77$ & $84.80 \pm 9.58$ \\
\hline \multirow[t]{3}{*}{5 ve üstünde } & 112 & $36.86 \pm 4.99$ & $32.39 \pm 6.09$ & $17.19 \pm 3.71$ & $86.45 \pm 10.60$ \\
\hline & & $* * \mathrm{~F}=0.836$ & $* * \mathrm{~F}=2.693$ & $* * \mathrm{~F}=0.753$ & $* * \mathrm{~F}=0.993$ \\
\hline & & $p=0.524$ & $p=0.020$ & $p=0.584$ & $p=0.421$ \\
\hline \multicolumn{6}{|l|}{ Aile yapısı } \\
\hline Çekirdek & 516 & $34.40 \pm 4.70$ & $30.86 \pm 5.36$ & $17.50 \pm 3.58$ & $84.76 \pm 9.69$ \\
\hline \multirow[t]{3}{*}{ Geniş } & 83 & $37.19 \pm 3.93$ & $33.03 \pm 4.69$ & $16.90 \pm 3.25$ & $87.13 \pm 8.21$ \\
\hline & & $* \mathrm{t}=-1.442$ & $* \mathrm{t}=-3.483$ & $* \mathrm{t}=1.424$ & $* \mathrm{t}=-2.102$ \\
\hline & & $p=0.150$ & $p=0.001$ & $p=0.155$ & $p=0.036$ \\
\hline \multicolumn{6}{|c|}{ Anne eğitim düzeyi } \\
\hline Okuryazar değil & 83 & $36.51 \pm 5.02$ & $32.37 \pm 6.13$ & $17.15 \pm 3.75$ & $86.04 \pm 10.85$ \\
\hline Okuryazar & 43 & $37.30 \pm 5.01$ & $32.39 \pm 6.09$ & $17.69 \pm 4.12$ & $87.39 \pm 11.47$ \\
\hline İlkokul & 261 & $36.86 \pm 4.15$ & $31.25 \pm 4.79$ & $17.31 \pm 3.42$ & $85.43 \pm 8.68$ \\
\hline Ortaokul & 93 & $35.54 \pm 5.17$ & $30.12 \pm 5.61$ & $17.22 \pm 3.73$ & $82.90 \pm 9.48$ \\
\hline Lise & 91 & $35.95 \pm 4.34$ & $30.80 \pm 4.71$ & $17.61 \pm 2.90$ & $84.37 \pm 8.85$ \\
\hline \multirow[t]{3}{*}{ Üniversite } & 28 & $37.03 \pm 5.31$ & $29.46 \pm 6.26$ & $18.71 \pm 4.22$ & $85.21 \pm 11.17$ \\
\hline & & $* * \mathrm{~F}=1.725$ & $* * \mathrm{~F}=2.726$ & $* * \mathrm{~F}=1.050$ & $* * \mathrm{~F}=1.835$ \\
\hline & & $p=0.127$ & $p=0.019$ & $p=0.388$ & $p=0.104$ \\
\hline \multicolumn{6}{|c|}{ Baba eğitim düzeyi } \\
\hline Okuryazar değil & 21 & $34.80 \pm 6.31$ & $30.47 \pm 8.96$ & $15.66 \pm 4.18$ & $80.95 \pm 15.98$ \\
\hline Okuryazar & 22 & $35.36 \pm 5.78$ & $32.31 \pm 6.40$ & $17.36 \pm 3.86$ & $85.04 \pm 11.14$ \\
\hline İlkokul & 212 & $37.02 \pm 4.08$ & $31.82 \pm 4.75$ & $17.50 \pm 3.53$ & $86.34 \pm 8.77$ \\
\hline Ortaokul & 125 & $36.37 \pm 5.21$ & $31.44 \pm 4.80$ & $16.77 \pm 3.48$ & $84.59 \pm 9.44$ \\
\hline Lise & 123 & $36.16 \pm 4.26$ & $30.37 \pm 5.37$ & $17.60 \pm 3.28$ & $84.13 \pm 8.76$ \\
\hline \multirow[t]{3}{*}{ Üniversite } & 96 & $36.65 \pm 4.50$ & $30.25 \pm 5.65$ & $18.22 \pm 3.57$ & $85.13 \pm 9.79$ \\
\hline & & $* * \mathrm{~F}=1.565$ & $* * \mathrm{~F}=2.115$ & $* * \mathrm{~F}=2.991$ & $* * \mathrm{~F}=1.858$ \\
\hline & & $p=0.168$ & $p=0.062$ & $p=\mathbf{0 . 0 1 1}$ & $p=0.100$ \\
\hline \multicolumn{6}{|c|}{ Aile kurduğunda anne/baba ile birlikte yaşamayı isteme durumu } \\
\hline İsteyen & 389 & $36.76 \pm 4.47$ & $31.71 \pm 5.50$ & $17.56 \pm 3.60$ & $86.04 \pm 9.11$ \\
\hline \multirow[t]{3}{*}{ İstemeyen } & 210 & $36.05 \pm 4.83$ & $30.14 \pm 4.82$ & $17.13 \pm 3.42$ & $83.33 \pm 10.04$ \\
\hline & & $* \mathrm{t}=1.810$ & $* t=3.462$ & $* \mathrm{t}=1.418$ & $* t=3.346$ \\
\hline & & $p=0.071$ & $p=0.001$ & $p=0.157$ & $p=0.001$ \\
\hline
\end{tabular}

\footnotetext{
*Independent Sample t Test,
}

**One-Way Anova

Uysal ve arkadaşlarının çalışmasında çalışmamızla benzer şekilde cinsiyet ile yaşamı sınırlama alt boyutu arasında anlamlı fark bulunmuş $(p<0.05)$; yaşlıların aile üyeleri ile birlikte yaşama durumu ile puan ortalamaları arasında anlamlı fark bulunmamıştır $\quad(p>0.05)^{16} \quad$ Bizim çalışmamızda Uysal'ın çalışmasından farklı 
olarak evlenince anne/baba ile yaşamayı isteme durumu ve YATÖ ölçek toplam puan ve alt gruptan yaşliya yönelik olumlu ayrımcılık puan ortalaması arasında anlamlı fark bulunmuştur $(p<0.05)$.

Ulusal ölçekte yapılan bir diğer çalışmada katılımciların aile kurduktan sonra ebeveyn ile yaşamayı isteme durumu ile ölçek alt grupları arasında istatistiksel olarak önemli bir fark olmadığ $1(p>0.05)$ bulunmuştur. ${ }^{22}$

Hekim ve hemşirelerin YATÖ ölçeği kullanılarak yaşlı ayrımcılığına ilişkin tutumlarını belirlemeye yönelik yapılan çalışmada yaş, cinsiyet, meslek, eğitim durumu ile ölçek ve alt grup puan ortalamaları arasında anlamlı fark bulunmamıștır $(p>0.05) .{ }^{23}$ Yetişkinler üzerinde yapılan bir başka çalışmada yetişkin eğitiminin yaşlıya yönelik tutumu etkilediği; örgün ve yaygın eğitimde yaşl1lıkla ilgili konulara yer verilmesinin önemi belirtilmektedir. ${ }^{7}$

Sağlık profesyonelinin yaşlıya yönelik tutumları ve kurum politikaları yaşlıya verdikleri hizmeti etkileyebilmektedir. Özellikle kronik hastalığı olan yaşlılara hizmet veren sağlık profesyonelleri zaman zaman yaşlı hastaları imal edebilmektedir. Winterstein sağlı profesyonellerinin mesleki değeri koruma ve kişisel değerleri sürdürme bağlamında yaşlılığa yönelik konuları içselleştirmesinin önemini vurgulamıştır. ${ }^{13}$ Ayrica yaşlilara yönelik olumlu tutum sergilemenin yaşlılara ayrılan kaynakların tedavide etkili kullanılmasına ve ihmali önlemede yardımcı olacağını belirtmiştir. ${ }^{13}$

Geriatri merkezinde çalışan sağlık profesyonelleri ve idari personel üzerinde yapılan bir katılımcıların YATÖ toplam puan ortalaması 68,40 ; çekirdek aile yapısına sahip olanların puan ortalaması düşük, yaşamın bir döneminde yaşlı ile birlikte yaşayanların yaşlıya yönelik olumlu ayrımcılık puan ortalaması daha yüksek bulunmuştur. ${ }^{24}$ Geriatri merkezinde çalışanların ortalama çalışma sürelerinin 5 yılın üzerinde olup yaşlıya yönelik pozitif tutumlarının düşük olduğu görülmektedir. ${ }^{24} \mathrm{Bu}$ çalışmada katılımcılar çalışmamız katılımcılarına göre yaşlıya yönelik daha olumsuz tutuma sahiptirler.
Hobbs ve arkadaşlarının çalışmasında fizyoterapi eğitimi sonrasında öğrencilerin yaşlilara yönelik olumsuz tutuma sahip olanların olduğunu; tutumu olumluya çevirmede eğitmenlerin tutumlarının önemli olduğuna vurgu yapmaktadır. ${ }^{12}$ İki kültürü karşılaştıran çalışmada Çinli öğrencilerin Amerikalı öğrencilere göre yaşlılara yönelik daha negatif tutum sergilediği bulunmuştur. ${ }^{25}$ Aynı çalışmada büyükanne büyükbaba ile yaşayan ya da onlarla etkileşim halinde bulunan öğrencilerin yaşlilara yönelik daha olumlu tutum sergilediği görülmüştür. ${ }^{25} \mathrm{Bu}$ çalışmada kültürel özelliklerin yaşlıya yönelik tutumda etkili olduğuna vurgu yapılmaktadır. ${ }^{25} \mathrm{Bu}$ da çalışmamız sonuçları ile benzerlik göstermektedir. Kültürel değerler yaşlıya yaklaşımı etkileyen önemli unsurlardan biridir. Fizyoterapi öğrencilerinin yaşlılara yönelik tutumlarını belirlemeye yönelik yapılan ulusal ölçekteki bir çalışmada kültürel değerlerin yaşliya yönelik tutumua etkilediği vurgulanmıştır. ${ }^{27} \mathrm{Bu}$ çalışmada lisans döneminde geriatrik rehabilitasyonla ilgili bilimsel etkinliğe katılımın yaşlıya yönelik tutumu olumlu etkileyeceğ $i$ belirtilmiş bu bağlamda geriatrik rehabilitasyonla ilgili programların arttırılmasının önemli olduğu saptanmıştır. ${ }^{27}$ Fizyoterapi ve ergoterapi alanında eğitim verenlerin ve son sinıf öğrencilerin yaşlilığa yönelik tutumlarını belirlemeye yönelik yapılan çalışmada öğrencilerin yaşlıya yönelik tutumlarının daha olumsuz olduğu ve bunun endişe verici olduğu belirtilmiştir. ${ }^{28}$ Çalışmada yaşlılıkla ilgili- bağlantılı lisansüstü eğitimin, müfredatta yaşlılıkla ilgili konulara yer verilmesinin önemi vurgulanmaktadır. ${ }^{28}$ Sosyal gerontoloji ve fizyoterapi öğrencilerinin yaşlılara yönelik tutumlarını belirleyen çalışmada erkeklerin daha olumsuz tutuma, fizyoterapi öğrencilerinin yaşlıya yönelik olumsuz tutuma; bir yaşlı ile beraber yaşayanların daha olumlu tutuma sahip olduğu saptanmıştır. ${ }^{29}$ Yazıcı ve ark sağlık bilimlerinde okuyan öğrenciler üzerindeki çalışmasında hemşirelik öğrencilerinin fizyoterapi ve yaşlı bakımı bölümü öğrencilerine göre puan ortalamaları daha yükssek bulunmuştur. ${ }^{30}$ Aynı çalışmada kadın öğrencilerin daha olumlu tutuma sahip olduğu, genel olarak öğrencilerin yaşlılara 
yönelik zayıf pozitif tutuma sahip olduğu saptanmıştır. ${ }^{30}$ Çalışmamızda ise Fizyoterapi öğrencilerinin puan ortalamasının daha yüksek olduğu bulunmuştur. $\mathrm{Bu}$ da öğrencilerin yaşliya ve yaşlılığa ilişkin daha olumlu tutuma sahip olduklarını söylemek mümkündür.

Sağlık bilimleri alanında eğitim gören öğrencileri ile yapılan çalışmada yaşlılığa ait bilgilerinin orta düzeyde olduğu ve yaşl1lığa yönelik pozitif tutuma sahip oldukları saptanmıştır. ${ }^{26} \mathrm{Bu}$ çalışmada öğrencilerin yaş ayrımcılı̆g 1 konusunda daha çok bilgilendirilmeleri gerektiği öğrencilerin geriatri kurumlarında uygulama yapmalarının olumlu tutum geliştirmelerine katk1 sağlayacağ 1 vurgulanmaktadır. ${ }^{26}$

\section{Araştırmanın Kısıtlılıkları}

$\mathrm{Bu}$ çalışma araştırmanın yapıldığ 1 bölümlerdeki katılımcılar ile sınırlıdır.

\section{Sonuç}

Katılımcıların YATÖ puan ortalamasının yüksek olduğu bulunmuştur. Bölümler arasındaki puan farklarına bakıldığında fizik tedavi ve rehabilitasyon bölümü öğrencilerinin YATÖ toplam puan ve yaşlının yaşamını sınırlama puan ortalamalarının hemşirelik öğrencilerine göre daha yüksek bulunmuştur. Yaşlıya yönelik tutum ile aile yapısı arasında anlamlı ilişki olduğu bulunmuştur. Geniş aileye sahip katılımcilarda YATÖ puan ortalaması, yaşlının yaşamını sınırlama ve olumlu tutum alt grup puan ortalaması çekirdek aileye sahip olanlara göre daha yüksek bulunmuştur. Aile kurduğunda ebeveynleri ile yaşamayı isteme durumu olumlu olan katılımcıların ölçek toplam puan ve alt gruplar toplam puan ortalamalarının daha yüksek olduğu bulunmuştur. Çalışmamızda sosyodemografik değişiklikler arasında yer alan büyükanne/büyükbabanın yaşadığı yer, ailenin gelir durumu, en uzun yaşanılan yerleşim birimi, medeni durum ve yaş değişkenleri ile YATÖ toplam puan ve alt grup puan ortalamaları arasında anlamlı ilişki bulunmamıştır. Yaşlıya yönelik olumlu tutum geliştirme bağlamında eğitim süresince verilen derslerde yaşlı ayrımcılığına yönelik konulara da yer verilmesi bu konudaki farkındalığ 1 arttıracaktır.

\section{Araştırmanın Etik Boyutu}

Çalışmanın yapıldığı A Üniversitesi Sağlık Yüksekokulu Müdürlüğü'nden ve Fizik Tedavi ve Rehabilitasyon Yüksekokulu Müdürlüğü'nden yazılı izin, sonrasında A Üniversitesi Klinik Araştırmalar Etik Kurulu'ndan izin alınmıştır (22.10.2015 tarihli toplantı Karar No: 4). Çalışma, Helsinki Bildirgesi ilkelerine bağlı kalarak yürütülmüştür.

\section{Bilgilendirilmiş Onam}

Katılımcılara araştırmacılar tarafindan çalışmanın amacını ve içeriğini kapsayan bilgi verilmiş, bilgilenme sonrası araştırmaya katılmayı kabul edenlere veri toplama formu dağıtılmış ve doldurmaları istenmiştir. Çalışmaya katılım tamamen gönüllülük esasına dayanmıştır.

\section{Yazar Katkıları}

Fikir/Kavram: R.C., H.T.; Tasarım: R.C., H.T., E.D.H., F.D.; Veri Toplama ve/veya İşleme: R.C., E.D.H., F.D.; Analiz ve/veya Yorum: R.C., H.T.; Kaynak Taraması: R.C., E.D.H., F.D.; Makalenin Yazımı: R.C.; Eleştirel İnceleme: R.C., H.T., E.D.H., F.D.

\section{Çıkar Çatışması Beyanı}

Yazarların herhangi bir çıkara dayalı ilişkisi yoktur.

\section{Araştırma Desteği}

$\mathrm{Bu}$ çalışma A Üniversitesi Bilimsel Araştırma Projeleri Kurum Koordinatörlüğü tarafindan 15381 nolu proje olarak desteklenmiştir.

\section{Beyanlar}

Çalışma 3-5 Mayıs 2018 tarihleri arasında düzenlenen 4. Uluslararası Sağlık ve Spor Bilimleri Sempozyumu'nda sözlü bildiri olarak sunulmuştur.

\section{Kaynaklar}

1. http://www.tuik.gov.tr/UstMenu.do?metod=temelist Erişim: 11.06.2019. 
2. Vefikuluçay D. Üniversitede Öğrenim Gören Öğrencilerin Yaşlı Ayrımcılığına İlişkin Tutumları. Hacettepe Üniversitesi Sağlık Bilimleri Enstitüsü Doğum ve Kadın Hastalıkları Hemșireliği Programı Doktora Tezi Ankara 2008.

3. Telatar TG, Özcebe H. Yaşlı Nüfus ve Yaşam Kalitesinin Yükseltilmesi. Türk Geriatri Dergisi 2004; 7 (3): 162-5.

4. Cangöz B. Yaşlılık: Sadece Kayıp Mı? Bir Ayrıcalık Mı?. Turkish Journal of Geriatric 2008; 11 (3): 143-150.

5. Bayraktar R. Yaşlılıkta Biyolojik ve Psiko-Sosyal Belirleyiciler. Geriatri ve Geriatrik Nöropsikiyatri Dergisi 2009; 1: 7-8.

6. Aydın ZD. Toplum ve Birey İçin Sağlıklı Yaşlanma: Yaşam Biçiminin Rolü. SDÜ Tıp Fakültesi Dergisi 2006; 13 (4): 43-8.

7. Komşu UC. Yaşlılık, Yaşlı Nüfusun Sorunları ve Yetișkin Eğitimi. Akademik Sosyal Araştırmalar Dergisi 2014; 2(1): 370-389.

8. Inbar N, Doron I, Ohory A. Physiotherapists' Attitudes Towards Old And Young Patients in Persistent Vegetative State (PVS). Quality in Ageing and Older Adults 2012; 13 (2): 111124.

9. Söderhamn O, Lindencrona C, Gustavsson SM. Attitudes Toward Older People Among Nursing Students And Registered Nurses in Sweden. Nurse Education Today 2001; 21: 225-9.

10. Rue BM. Preventıng Ageism In Nursing Students: An Action Theory Approach. Australian Journal of Advanced Nursing 2003; 20 (4): 8-14.

11. Ucun Y, Sevinç M, Öksüz E. Gençlerin Yaşlı Bireylere Karş1 Tutumu. Uluslararası Sosyal Araştırmalar Dergisi 2015; 8; (37): 1143-9.

12. Hobbs C, Dean MC, Higgs J, Adamson B. Physiotherapy Students' Attitudes Towards And Knowledge of Older People. The Australian Journal of Physiotherapy 2006; 52: 115-9.

13. Winterstein TB. Health Care Provision For Older Persons: The İnterplay Between Ageism And Elder Neglect. Journal of Applied Gerontology 2013; 20 (10): 1-15.

14. Altay B, Aydın T. Hemşirelik Öğrencilerinin Yaşlı Ayrımcılığına İlişkin Tutumlarının Değerlendirilmesi. Hemșirelikte Eğitim ve Araștırma Dergisi 2015; 12 (1): 11-18.

15. Vefikuluçay Yılmaz D, Terzioğlu F. Development And Psychometric Evaluation Of Ageism Attitude Scale Among The University Students. Turkish Journal of Geriatrics 2011; 14 (3) : 259-268.

16. Uysal G, Beydağ KD, Şensoy F, Özaydın N, Kıyak M. Attitudes Of Students Who Receive Health Education in a Foundation University Regarding Age Discrimination. Social and Behavioral Sciences 2014; $152 ; 430-4$.

17. Soyuer F, Ünalan D, Güleser N, Elmalı F. Sağlık Meslek Yüksekokulu Öğrencilerinin Yaşlı Ayrımcılığına İlișkin Tutumları ve Bu Tutumların Bazı Demografik Değişkenlerle İlişkisi. Mersin Ü Sağllk Bil Dergisi 2010; 3 (2): 20-5.

18. Kulakçı H. Hemşirelik Lisans Programı Birinci Ve Dördüncü Sınıf Öğrencilerinin Yaşlılık Ve Yaşlanmaya İlişkin Düșüncelerinin ve Görüșlerinin Değerlendirilmesi. DEUHYO ED 2010; $3 \quad$ (1), 3 15-22 Erişim: http://www.deuhyoedergi.org/index.php/DEUHYOED

19. Yılmaz E, Özkan S. Hemşirelik Öğrencilerinin Yaşlı Ayrımcılığına İlişkin Tutumları. Maltepe Üniversitesi Hemșirelik Bilim ve Sanatı Dergisi 2010; 3 (2): 35-53.

20. Sheikh RB, Em MD, Rafiue AM, Suraweera RSC, Khan H, Sreedharan J. Attitude of Medical Students Toward Old People in Ajman United Arab Emirates. Asian J Gerontol Geriatr 2013; 8: 85-9.

21. Karadağ E, Vardar İnkaya B, Karatay G. Hemşirelik Öğrencilerinin Yaşlı Ayrımcılığına İlişkin Tutumları. Ege Üniversitesi Hemşirelik Fakültesi Dergisi 2012; 28 (2) : 31-40.

22. Güven ŞD, Ucakan Muz G, Efe Ertürk N. Üniversite Öğrencilerinin Yaşlı Ayrımcılığına İlişkin Tutumları Ve Bu Tutumların Bazı Değişkenlerle İlişkisi. Anadolu Hemşirelik ve Sağllk Bilimleri Dergisi 2012; 15 (2): 99-105.

23. Polat Ü, Karadağ A, Ülger Z, Demir N. Nurses' And Physicians' Perceptions Of Older People And Attitudes Towards Older People: Ageism In A Hospital In Turkey. Contemporary Nurse 2014; 48(1): 88-97.

24. Ünalan D, Soyuer F ve Elmalı F. Geriatri Merkezi Çalışanlarında Yaşlı Tutumunun Değerlendirilmesi. Kafkas Tıp Bilimleri Dergisi 2012; 2(3); 115-120.
25. Luo B; Zhou K, Jung Jin E, Newman A, Liang J. Ageism among college students: a comparative study between U.S. and China. J Cross Cult Gerontol 2007; 28:49-63.

26. Singh DKA, Subramaniam P, Rahman NNAA, Rusly FZ, Ghazali SE. Knowledge and Attitude Towards Ageing Among Health Science University Students. J Liaquat Uni Med Health Sci 2018; 17(01):36-41.

27. Bakırhan S, Özkeskin M, Aktar Reyhanioğlu D, Gülpınar D. Analysis of the Attitudes And Approaches Of The Physiotherapy And Rehabilitation Students Towards The Elderly. Turkish Journal of Geriatrics 2017; 20 (2):125-134.

28. Lynne C. Giles, Janis E. Paterson, Sarnia J. Butler \& Jenny J. Stewart. Ageism Among Health Professionals: A Comparison Of Clinical Educators And Students İn Physical And Occupational Therapy. Physical \& Occupational Therapy In Geriatrics 2002; 21(2): 15-26.

29. Kaker DJ, Ovsenik M, Zupančič J. Attitudes of Social Gerontology And Physiotherapy Students Towards The Elderly. Organizacija 2016; 49: 55-69.

30. Yazıcı SÖ, Kalaycı I, Kaya E, Tekin A. Sağlıkla İlgili Bölümlerde Okuyan Öğrencilerin Yaşlilara Yönelik Tutumları. Gaziantep University Journal of Social Sciences 2016; 15(2):601-14. 